\title{
Molecular Labeling of DNA Amyloid Sensor with Plasma, and the Glycemic Factor, for Photonic Detection of Alzheimer's in Blood
}

\author{
Cuero $\mathrm{R}^{1,2 *}$, Agudelo $\mathrm{D}^{2}$, Sanchez $\mathrm{L}^{2}$ and Londono $\mathrm{J}^{2}$ \\ ${ }^{1}$ BioCapital Holdings, LLC, Houston, USA \\ ${ }^{2}$ International Park of Creativity Center, Manizales, Colombia
}

\begin{abstract}
This investigation was carried out based on the integrative approach at the cellular, molecular and atomic level. Therefore, our aim was to develop two DNA sensors that detect Alzheimer's disease related $\beta$-amyloid protein in blood using synthetic and molecular biology. The DNA sensors were constructed in $E$. Coli or Saccharomyces cerevisiae using genetic sequences and they were tested in terms of fluorescence expression units (FSU) when mixed with human blood plasma using a fluorescence detector. This amyloid sensor was also confirmed using photonic Raman technology, and corroborated by analyzing the purified protein using SDS-PAGE gel electrophoresis, which product was confirmed by using different sizes of Macrosep Advance Centrifugal devices. The intensity of the detection was enhanced by labeling the fluorescence targeted molecules in samples which were conjugated with fluorescent dyes.

Fluorescence results were comparable to clinical and MRI results. The DNA sensor was able to detect $\beta$-amyloid protein in different type of patients. Results were also correlated with the glycemic levels of the patients. Influence of metals on expression of amyloid protein was also demonstrated through ELISA and Western Blot assays. Due to the highly correlation between fluorescence intensity and levels of $\beta$-amyloid, these results were used to classify patients according to the severity of Alzheimer's (i.e. Group1: Alzheimer's Diagnosed; Group2: Pre-Alzheimer's; and Group3: Normal) in addition to clinical medical symptoms (e.g., memory loss, cognitive impairment such as mental disorientation and/or mental confusion) and MRI results. Statistical analysis showed that the groups were well categorized based on the three selected parameters. Group 1 showed the highest fluorescence total mean followed by Group 2, as compared to Group 3, which exhibited the lowest total mean. Gender seemed to be an associate factor at time of the disease onset.
\end{abstract}

These results suggest the advantage of using this method for early detection of Alzheimer's disease as well as the importance of metals for triggering the expression of $\beta$-amyloid protein.

\section{Introduction}

Proteins such as amyloid are identified by conventional molecular weight methods such as SDS-PAGE gel electrophoresis [1]. Proteins are mainly recognized by their molecular weight, which can be identified and quantified by conventional methodology along with the use of Macrosep centrifugal devices [2]. In addition to gel electrophoresis, Western Blot and ELISA techniques are reliable molecluar methods for assaying proteins such as amyloid or by photonicity Raman spectroscopy. The relationship between the optical behavior of living cells and photon emission has been demonstrated by other authors, suggesting that living organisms and/or cells are subject to excitation by a wide spectrum of photon intensities [3]. Techniques such as Raman, which is based on photonicity, has been used for detecting amyloid proteins. Raman scattering is a two-photon process that involves the molecular interactions with light using laser beams as the light source in order to emit a photon that exchanges energy with the vibrating molecule [4]. Thus, enhancing intensity would result in better detection of targeted molecules such as $\beta$-amyloid protein.

Other photonicity technology such as ZetaSizers has also been used for the identification of amyloid protein [5] [6]. Also, previous research has reported the influence of metals in the brain in relation to Alzheimer's disease [7].

\section{Materials and methods}

\section{Construction of DNA sensor}

Synthesized DNA sequences from CloneTex Systems, Inc (Austin, TX) were assembled in pBSKII or pYES2 plasmid, employing standard experimental laboratory protocols [8-10]. Both bacterial or yeast DNA sensors were constructed by site-directed cloning with specific primers as provided below. However, only the yeast DNA sensor was used to detect $\beta$-amyloid in patient blood related to Alzheimer's (Figure 1). While the DNA bacterial sensor was used for in vitro determination of $\beta$-amyloid protein using ELISA method.

\section{Preparation of DNA construct}

The DNA constructs were composed of genetic components described herein and assembled in plasmid vectors (i.e. pBSKII or pYES2). Sequences of genes and/or proteins with desired properties

${ }^{*}$ Correspondence to: Cuero R, PhD, 15310 Misty Dawn, Trl Cypress, TX, USA, Tel: (832) 477-5510; E-mail: olimpa@aol.com

Key words: alzheimer's, amyloid, diabetes, dna sensor, glycemic, synthetic biology, photonicity, raman

Received: June 05, 2020; Accepted: June 15, 2020; Published: June 21, 2020 
were identified in GenBank. The DNA constructs were made with similar gene parts having sequence sizes ranging from 747 to 1300 bp. These included different gene sequences with respective accession number: amyloid precursor protein gene (no. NM_201414.2) and a TonB gene (no. ACB93044.1). Other genetic parts were also obtained for inserting in the DNA constructs including, T7 promoter gene, iron promoter gene (no. CP015495.1), yellow fluorescent reporter protein (no. JQ394803.1), and riboswitch TC aptamer (no. D26134.1). However, the transferrin protein was added to the yeast DNA construct. These genetic parts included restriction sites for ease of insertion into plasmid.

This procedure was carried out by combining standard experimental laboratory methods of molecular and synthetic biology [11]. Each gene was amplified by PCR with gene-specific primers with added restriction sites where needed.

\section{Cloning of the genetic parts into the bacterial or yeast device}

The cloning of the genetic parts into the bacterial and yeast devices were performed as follows. Sequences of individual genes were amplified by PCR, using gene-specific primers. Genes were excised from plasmids following a protocol supplied by Promega (Madison, WI). The excised fragments were purified by agarose gel electrophoresis prior to ligation.

\section{Ligation process}

A pBSKII or pYES2 plasmid already containing a gene for the amyloid precursor protein was then digested with HindIII restriction enzyme according to directions and using reagents provided by the enzyme's supplier (Promega, Madison, WI). The complete insert containing HindIII restriction sites on each end was ligated into the plasmid following protocol of Promega (Madison, WI). The reaction mixture was placed into an electromagnetic chamber for ligation and/ or transformation and subjected to a minicurrent $(900 \mathrm{~mA})$ magnetic field with a strength of 0.35 Gauss. Successful construction of the insert and ligation [10] of the insert into the plasmid were confirmed by gel electrophoresis.

\section{Host cell purification and transformation}

Competent E. coli cells (One Shot, Top 10, Invitrogen) or yeast cells (INVSc1 yeast host strain, Invitrogen) were transformed with the DNA construct described herein using a modified version of a protocol provided by the supplier, [11]. A fully assembled S. cerevisiae device was sub-cloned into pYES2 vector.

DNA expression and effectiveness of transformation were determined by the number of colonies present using a 20/20 Luminometer (Promega). Plasmid DNA extraction purification, PCR, and gel electrophoresis were also used to confirm transformation.

\section{Construction of synthetic amyloid standard}

Construction of the synthetic amyloid standard was carried out by Clonetex Systems, Inc, Austin, TX, USA). Soluble amyloid precursor protein-alfa was provided by Clonetex Systems Inc, Austin, Tx, USA. cDNA corresponding to amino acids 304-612 in human amyloid precursor protein was codon optimized and synthesized for its expression as 6xHis-tag secreted human sAPPa recombinant protein in E.coli. Briefly, synthetic gene was cloned into pET28A expression vector and recombinant sAPP $\alpha$ protein was expressed in BL21 (DE3) strain of E.coli. Expressed protein was affinity purified on Ni-Sepharose column.

\section{Effect of metal ions on $\boldsymbol{\beta}$-Amyloid protein expression}

The effect of metal ions on both growth of the DNA $\beta$-amyloid bacterial sensor and the production of the $\beta$-amyloid protein by the bacterial sensor were determined as provided below.

\section{Determination of $\beta$-Amyloid protein by ELISA}

A culture of $E$. coli transformed with DNA $\beta$-amyloid device in the pBSK II was subjected to extraction of $\beta$-amyloid protein. Production of cell pellet was obtained prior to the extraction of the protein following standard procedures [8] and protocol provided by Open Biotechnology protein extraction kit (ThermoFisher, Waltham, MA). Cells of the DNA bacterial device were grown in different concentrations of $\mathrm{LB}+$ ampicillin liquid medium at $37^{\circ} \mathrm{C}$ for 7 hours and 4 hours. Cell growth was determined by absorbance at 550-600 nm. Next, grown cells were subjected to centrifugation in order to obtain final pellet, which was subjected to isolation of $\beta$-amyloid using the Open Biotechnology protein extraction kit (ThermoFisher, Waltham, MA). Finally, the pellet was lysed with lysozyme and the homogenized solution was subjected to different temperatures.

The Alpha Diagnostic International $\beta$-amyloid 1-42 ELISA kit (San Antonio, TX) was used to determine $\beta$-amyloid protein production plate and compared to different concentrations of $\beta$-amyloid standards. Different concentrations of the extracted $\beta$-amyloid protein from the DNA $\beta$-amyloid device culture grown with or without metals were determined in different wells of the ELISA. The color intensity of the sample was also used to determine the concentration of the amyloid protein the higher the color intensity the higher the concentration of protein. Figure 2 provides the ELISA assay for $\beta$-amyloid protein with or without metal ions.

\section{Determination of $\beta$-Amyloid protein in patient blood samples by western blot}

$\beta$-Amyloid protein was identified from patients by using standard methods [8]. Protein was quantified in two human plasma samples and the volume was adjusted to yield $2 \mathrm{mg} / \mathrm{mL}$ protein in each sample, where an equal volume of buffer was used as a control. Another human blood plasma sample was also analyzed however, due to the lack of homogeneity, low volume, and lack of consistency during the initial preparation of this sample, this result is not shown herein. Equal amounts of protein in two sets of samples at $15 \mu \mathrm{g} / \mathrm{mL}$ and $30 \mu \mathrm{g} / \mathrm{mL}$ in Laemmle sample buffer were used and subsequently electrophoresed on $8-16 \%$ gradient SDS-polyacrylamide gel. The results from samples of $30 \mu \mathrm{g} / \mathrm{mL}$ of protein are only presented herein. The proteins were transferred to a PVDF (polyvinylidene difluoride) membrane and subjected to blotting including an anti-Mouse $\beta$-Amyloid Monoclonal Antibody (AMY-33). The blotted membrane was subjected to a series of washing steps in TBST buffer. The antigen-antibody complexes were visualized using enhanced chemiluminescence (ECL-2, Thermo Scientific, Rockford, CA). Figure 3 provides the Western Blot test for $\beta$-amyloid protein from patient's blood plasma. Similar Western Blot analysis was carried out for extract of DNA amyloid yeast sensor mixed with plasma from healthy patient or diagnosed Alzheimer's patient.

\section{Production of extract from DNA amyloid yeast cells device}

Extract/lysate/recombinant protein from three days of cultured yeast cell device was obtained after a process of sonication and filtration ( $<3$ micron), and lyophilization. This extract was mixed with blood plasma (3:1). 


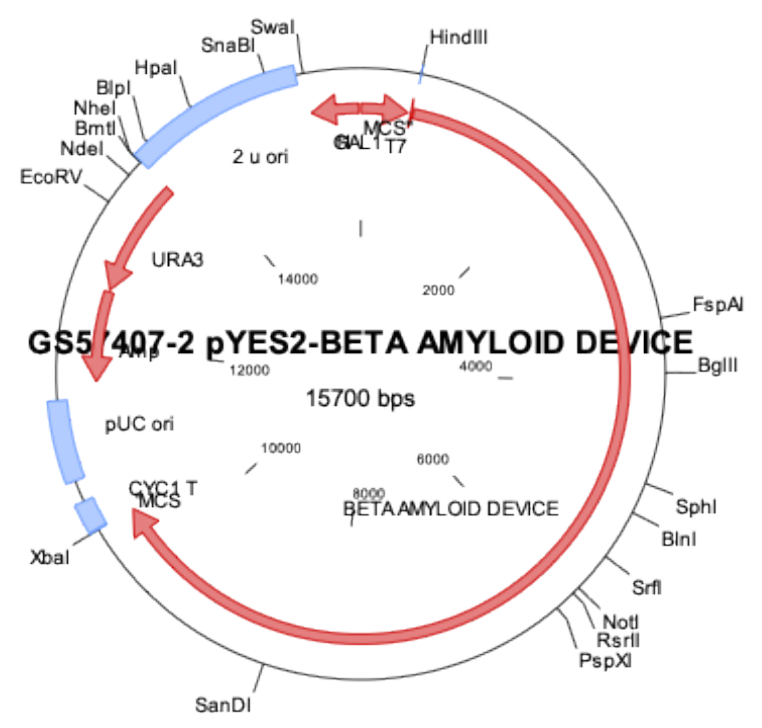

Figure 1. Schematic illustration of $\beta$-amyloid sensor construct. Illustration shows the direction, placement and size of the DNA construct for the $\beta$-amyloid sensor beginning with T7 promoter, amyloid precursor protein, riboswitch TC aptamer, TonB, and yellow reporter protein sequences in the constructed plasmid

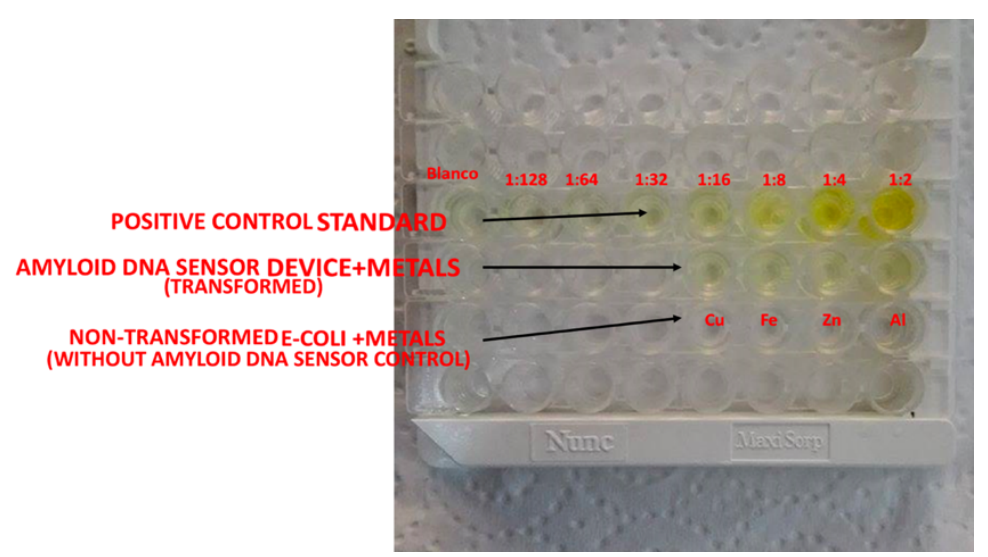

Figure 2. ELISA assay for $\beta$-amyloid protein with or without metal ions. ELISA showing expression of $\beta$-amyloid protein from samples of $\beta$-amyloid sensor cells grown in presence of different metal ions $\left(\mathrm{Cu}^{2+}, \mathrm{Fe}^{2+}, \mathrm{Zn}^{2+}\right.$ and $\left.\mathrm{Al}^{2+}\right)$ as compared to a control (non-transformed E. coli cells)

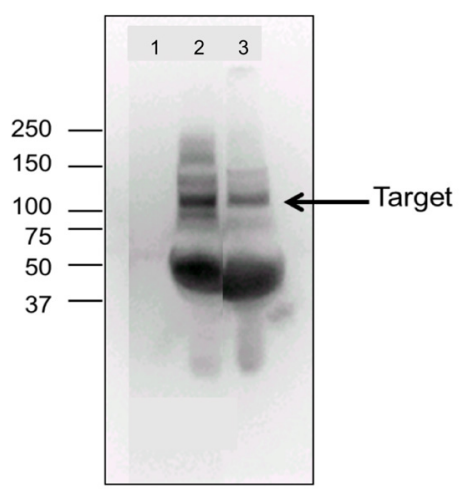

(A)

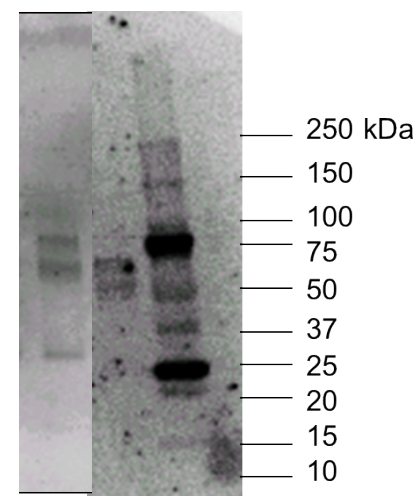

(B)

Figure 3. A. is the western blot test for $\square$-amyloid protein from patient's blood plasma. This figure shows a band specific to $\square$-amyloid in samples of patients with high $\square$-amyloid fluorescence and clinically diagnosed with Alzheimer's symptoms as compared to a healthy patient with low $\beta$-amyloid fluorescence.1. buffer (control). 2. patient with higher $\square$-amyloid fluorescence and clinical Alzheimer's symptoms, and 3. patient with low $\square$-amyloid fluorescence and no clinically diagnosed Alzheimer's. The patient samples (lane 2 and lane 3) are plasma samples at $30 \mu \mathrm{g} /$ lane. Primary Antibody (Mouse $\square$-amyloid monoclonal antibody (AMY-33) Cat\# 13-0100Z Thermofisher) $2 \mu \mathrm{g} / \mathrm{mL}$, 2hr RTP. Secondary: Goat Anti Mm -HRP- 1:5K dilution. B. is the Western Blot test for $\square$-amyloid protein from mixture of extract of DNA amyloid yeast with blood plasma from healthy patient (first lane), and Diagnosed Alzheimer's patient (second lane), as compared to standard, STD (third lane). This figure shows darker bands for sample of diagnosed Alzheimer's patient (lane 2), as compared to sample from healthy patient which shows lighter bands. Hence, the mixture of the extract of the DNA amyloid sensor with plasma showed higher expression of the protein in diagnosed Alzheimer's patient as compared to healthy 


\section{Determination of amyloid protein in blood plasma samples by raman photonic spectroscopy}

Raman spectroscopy (RENISHAW INVIA CONFOCAL RAMAN SPECTROMETER, UK) was used to detect the presence of amyloid protein in plasma of patients for each group. Analysis was done for each plasma sample and their corresponding mixture of the DNA amyloid sensor plus plasma. Two replicates per non-conjugated sample per group were analyzed by Raman spectroscopy. One hundred to two hundred $\mathrm{mL}$ plasma samples were used for Raman analysis and compared to amyloid standard. The laser was used at wavelengths between $532 \mathrm{~nm}-785 \mathrm{~nm}$ at $10 \%$ laser intensity. Sample intensity and Raman shift $(1 / \mathrm{cm})$ were used as a measurement parameter. Results were obtained based on parameters above. Raman intensity is affected by light source intensity, upon $1 /$ lamb $\wedge 4$ of source wavelength, concentration of sample or number of molecules, and scattering properties of the sample. All spectra were gathered with a $785-\mathrm{nm}$ excitation laser with $10 \mathrm{sec}$ exposure and 4 acquisitions using a $1 \mathrm{~mm}$ quartz cuvette at $25^{\circ} \mathrm{C}$. Spectra was processed and analyzed using BioRad KNOWITALL INFORMATICS SYSTEMS 2018.

\section{Determination of particle size of the DNA amyloid sensor}

Purified amyloid extract from the DNA amyloid culture was diluted with $500 \mathrm{mmol}$ Tris. The concentration was measured by drying the solution in an oven at $55^{\circ} \mathrm{C}$ for 24 hours. The concentration of the supernatant was determined as $76.25 \mathrm{mg} / \mathrm{mL}$, where $1 \mathrm{x}, 2 \mathrm{x}$ and $5 \mathrm{x}$ solutions with $500 \mathrm{mMol}$ Tris were prepared for measurement. Next, a sample of $700 \mu \mathrm{L}$ of the solution was transferred into a quartz cuvette to be placed in the Malvern Zetasizer Nano, UK for determining the molecular weight of the protein. The Zetasizer instrument is capable of measuring particle and molecular size from less than a nanometer to several microns using dynamic light scattering; zeta potential and electrophoretic mobility using electrophoretic light scattering; and molecular weight using static light scattering.

Determination of molecular weight by centrifugal device and gel electrophoresis

Extract produced from the DNA amyloid transformed yeast culture was used for determining the molecular weight of the amyloid protein. Amyloid precursor protein produced in bacteria as a fragment $(45 \mathrm{kDa})$ (see above) was used as a control reference. Extract from the DNA amyloid yeast culture was produced through different steps including centrifugation for 190 minutes at $9000 \mathrm{rpm}$, pellet resuspension in nuclease free deionized water, followed by sonication at different cycles and centrifugation. The supernatant from centrifugation was filtered through $0.2 \mu \mathrm{m}$ or $0.45 \mu \mathrm{m}$ for the DNA amyloid bacteria culture or DNA amyloid yeast culture, respectively. This extract containing the amyloid protein was subjected to purification.

\section{Purification of alzheimer device protein by affinity chromatography (SDS-PAGE)}

The purity of the protein was determined by $12 \%$ SDS-PAGE gel electrophoresis. SDS-PAGE gel was prepared according to standard method (Sambrook and Russel, 2001). Acrylamide 12\% / Bis Solution (Plus One GE) was mixed with Tris- $\mathrm{HCl}, 0.1 \%$ SDS, ammonium persulfate (APS), tetramethylethylenediamine (TEMED). For the stacking gel, 5\% Acrylamide / Bis solution (Plus One GE), $125 \mathrm{mM}$ Tris- $\mathrm{HCl}, \mathrm{pH} 6.8,0.1 \%$ SDS, $0.05 \%$ APS, $0.1 \%$ TEMED was used. Electrophoresis was performed in running buffer containing $1 \mathrm{x}$ TrisGlycine (25 mM Tris, pH 8.3, $192 \mathrm{mM}$ glycine) and $0.1 \%$ SDS. The running conditions were 70 to $80 \mathrm{~V}, 400 \mathrm{~mA}$, and $30 \mathrm{~W}$.
The proteins were visualized after staining the gel with the dye Coomassie Brilliant Blue R-250 (Amresco) according to the supplier's instructions. The protein bands expressed on the gel were observed and the molecular weight was determined according the molecular weight ladder as standard reference. The eluted fractions were concentrated using Macrosep Advance Centrifugal $30 \mathrm{kDa}$ MWCO and $100 \mathrm{kDa}$ Omega (Pall Corporation) at $2300 \mathrm{rpm}$ for 2 hours at $4^{\circ} \mathrm{C}$.

\section{Enhancement of fluorescence, using non-radioactive labeling through molecular conjugation}

This method was carried out using a labeling kit protocol (NHS labeling protocol with the ester of the amino biomolecules Lumiprobe USA), which includes the Cy 3 dye to mark the specific side of the amyloid proteins. The following four steps were performed: 1) preparation of conjugation sample, 2) mixing of extract from DNA Amyloid culture with patient plasma, plus fluorophore, 3) purification of the labeled conjugated sample by a column, and centrifugation at $3800 \mathrm{rpm}, 4)$ photonicity detection of the sample, using GloMax ${ }^{\circ}$ Multi+ Detection System with Instinct ${ }^{\text {tix }}$ Software: Base Instrument with shaking (PROMEGA, Madison, Wisconsin USA) at different fluorescence modules (Green, Blue, UV, AFC, Red)

The advantage of using a marker such as the dye Cy3 is that it naturally bonds without being radio labeled to the targeting protein such as amyloid. Therefore, anytime a source of light comes in contact with this complex (Cy3 dye + DNA extract device), it will emit more fluorescence specific to the protein amyloid that is bonded to the dye.

\section{In vivo fluorescence determination of $\beta$-Amyloid in blood plasma samples from patients}

Fifty blood plasma samples from different patients were evaluated in the present investigation using the extract of the yeast cell sensor. Fluorescence (FSU) of the DNA $\beta$-amyloid sensor was measured in a GloMax Bioanalyzer Detector GloMax-Multi+ Detection System with Instinct ${ }^{\text {tw }}$ Software (Promega, Madison, WI) set at the wavelength range of $400-550 \mathrm{~nm}$ as a source of excitation. Fluorescence was correlated to the concentration of $\beta$-amyloid in blood plasma samples from patients and compared to the criteria of medical diagnosis for Alzheimer's disease. The fluorescence mechanism of the interaction between the source of photonic excitation-emission and the blood plasma sample mixed with the DNA $\beta$-amyloid in metals and the extract of the yeast cell sensor is shown on Figure 4, which is based on the excitation coupled with biophysical emission and biochemical principles [12].

Alzheimer's patients were divided in three groups ( $1=$ Alzheimer's Diagnosed; $2=$ Pre-Alzheimer's; $3=$ Normal $/$ Healthy). Blood plasma samples were used from the three different groups of patients according to their ranges of fluorescence and medical diagnosis criteria. All patients in the present investigation were within the age between 57 years-old to 89 years-old.

Samples were analyzed using the extract from the yeast cell sensor mixed with the blood plasma at a volume ratio of 3:1 (extract: blood plasma). The results were then divided in three groups according to the intensity of the fluorescence in relation to the medical diagnosis criteria for Alzheimer's disease as follows: Group 1/Alzheimer's diagnosed = 12,800-16,300 FSU; Group 2/Pre-Alzheimer's = 11,800-12,800 FSU; and Group 3/Healthy/Asymptomatic $=7,700-11,800$ FSU. The inherent fluorescence (FSU) of the extract from the yeast sensor (4,000 FSU) was subtracted from the final fluorescence in each sample. 


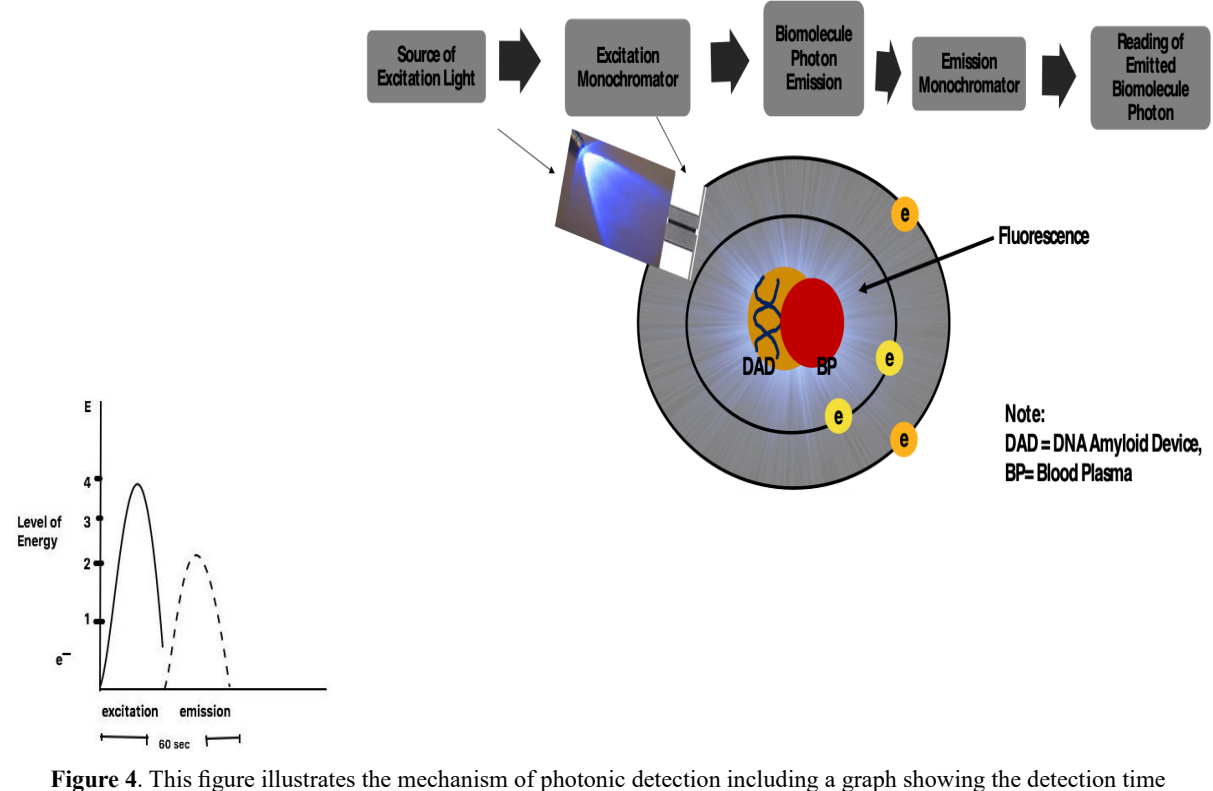

\section{In Vivo clinical glycemia determinations in blood plasma samples from patients}

Levels of glycemia were determined from patient's blood samples, and they were correlated to fluorescence (FSU) and to the clinical medical criteria. Glycemia analysis was also carried out at the clinical laboratory Alvarez-Medina, Cali-Colombia, and at DiagnostiMed Center, Manizales-Colombia. Glycemia analysis was also performed in blood plasma samples from patients following the American Diabetes Association protocol [20] based on the Glucose-Oxidase/PeroxidaseHexokinase test [13].

\section{Comparative analysis between fluorescence of the DNA} $\beta$-Amyloid sensor and MRI, and medical diagnosis

MRI analysis: Although both CT Scan and MRI Analysis were performed in patients, results from MRI are only shown in the denoted paper. CT Scan results (not shown) produced partial comparative results since it was mainly specific Alzheimer's Diagnosed patients, as compared to MRI, showed more specificity across patients. Therefore, MRI analysis was performed following the standard MRI protocol [14] at Diagnositmed Center, Manizales, Colombia. The analysis was carried out using radiofrequency pulse types Spin-eco and turbo Spin-eco with 1.5 Tesla magnet using GE equipment (Boston, MA). Imaging was created based on anatomic differentiation (i.e. T1 and T2) using the three-dimensional phase contrast.

\section{Statistical analysis}

Statistical Analysis was performed to categorize the patients in three groups (Diagnosed Alzheimer's, Pre-Alzheimer's, and Normal), using the Statgraphics Centurion Software version 16.1 (2017 Statgraphics Technologies, Inc., The Plains, Virginia). Hence, an analysis of variance (ANOVA) was carried out to determine the mean, standard deviation, variance, correlation ( $r$ ) between groups, and the type of gender within each group, the effect of age, and the p-value or level of significance of these correlations.

\section{Results}

\section{Construction of DNA Sensor}

Effective assembly of the DNA $\beta$-amyloid sensor (Figure 1) was confirmed by the high fluorescence intensity (i.e. 1,700 FSU) of the bacterial DNA $\beta$-amyloid sensor when grown in LB medium as compared to non-transformed competent $E$. coli cells (control), which expressed very low fluorescence when they were exposed to 20/20 Luminometer.

In vitro determination of the effect of metal ions on production of $\beta$-Amyloid protein in bacterial b-Amyloid device by ELISA

The ELISA results showed a higher concentration of $\beta$-amyloid protein in samples of $\beta$-amyloid device with higher volume of cells grown in the presence of metal ions as compared to non-transformed E. coli cells. The $\beta$-amyloid device grown in the presence of metal ions exhibited more yellowish intensity as compared to a non-transformed control (Figure 2).

A direct correlation exists between the influence of the metal ions and production of $\beta$-amyloid protein from the DNA $\beta$-amyloid device sensor. A direct correlation exists between the influence of the metal ions and the production of $\beta$-amyloid protein from the DNA $\beta$-amyloid device sensor. For instance, when the DNA amyloid sensor was grown in aluminum, iron, or copper, the sensor showed higher concentration of amyloid (200, 100, and $100 \mathrm{pg} / \mathrm{ml}$, respectively) as compared to control (i.e., cells without the DNA amyloid sensor), which showed negligible amyloid production.

\section{Determination of $\beta$-Amyloid protein in patient blood plasma samples using western blot}

Results from Western blot analysis showed bands with stronger intensity in the sample of a patient with high $\beta$-amyloid fluorescence ( $>158,000 \mathrm{FSU}$ ) and clinically reported with Alzheimer's symptoms as compared to a sample from a healthy patient (900 FSU) (Figure 4). 
Similar results were obtained for plasma samples mixed with extract of DNA amyloid yeast sensor, in which the sample from diagnosed Alzheimer's patient with higher fluorescence (12800 FSU) showed higher expression of the protein as compared to Healthy with lower fluorescence (10500 FSU) (Figure 4).

\section{In vitro test of fluorescence of DNA $\beta$-Amyloid device sensor}

Results showed higher fluorescence of the DNA $\beta$-amyloid sensor at different dilutions as compared to control (non-transformed E. coli or extract from the yeast cell sensor). A similar correlation was shown by the control sensor but with lower fluorescence (FSU). (data not shown)

\section{In vivo clinical alzheimer's determination as compared to fluorescence in blood plasma from patients}

The presence of $\beta$-amyloid protein was measured in vivo using human blood plasma samples. The results showed a direct correlation between higher fluorescence of $\beta$-amyloid and the medical report, which is based on the following criteria: 1. memory loss, and 2. cognitive impairment (e.g., mental disorientation, and/or mental confusion), as compared to a healthy patient. Hence, the Alzheimer's diagnosed Group 1 was directly correlated with the two criteria mentioned above, while the pre-Alzheimer's Group 2 showed correlation to one of the above-mentioned criteria, and in some cases, could be asymptomatic as compared to control Group 1 that is asymptomatic. Plasma samples mixed with yeast extract exhibited high fluorescence intensity. This intensity was enhanced more than 10-fold when both the mixture of plasma plus the extract of the DNA amyloid sensor was labeled with non-radioactive $\mathrm{Cy} 3$ dye, after conjugation (Table 1), as compared to samples of the mixture that were not labeled. Hence, Group 1 or Alzheimer's diagnosed showed the highest fluorescence intensity $($ mean $=158,100 \mathrm{FSU})$, as compared to non-labeled $($ mean $=13,800$ FSU); Group 2 or pre-Alzheimer's, which showed the second highest fluorescence intensity (mean $=127,700 \mathrm{FSU}$ ), as compared to nonlabeled (mean = 10,500 FSU); followed by Group 3 or control/healthy/ asymptomatic having the lowest fluorescence intensity (Mean $=82,200$ FSU), as compared to non-labeled (mean $=10,500 \mathrm{FSU}$ ). The preAlzheimer's Group 2 exhibited a mean of 127,700 FSU that was between the diagnosed Alzheimer's Group 1 and the healthy Group 3. Samples from women showed the highest $\beta$-amyloid fluorescence in Group 1 (140,000 - 183,600 FSU) (Table 1). In Group 2 (pre-Alzheimer's) the level of fluorescence was equally distributed amongst both genders. The $\beta$-amyloid sensor produced higher $\beta$-amyloid fluorescence in plasma samples in both genders. Group 1 showed higher $\beta$-amyloid fluorescence with patients between the age range of 70-89 years-old as compared to Group 2 patients, which showed lower amyloid fluorescence between the age range between 57-78 years-old. The variability of the level of fluorescence intensity was noticeable within the range of the Alzheimer's diagnosed Group 1 as compared to the pre-Alzheimer's Group 2 and healthy Group 1, which showed less variability within their narrower range. Although glycemic expression was used as a parameter to correlate the expression of $\beta$-amyloid device fluorescence, there was no direct correlation between $\beta$-amyloid samples from Alzheimer's' patient's glycemic levels with the yeast extract.

\section{Determination of amyloid protein in blood plasma samples by raman photonic spectroscopy}

Results of the Raman analysis show that intensity and the shift value of the amyloid protein correlate with the peaks of the sample but the range size depended on the type of patient group and type of sample (i.e. plasma alone, or plasma + extract of DNA amyloid sensor). Thus, the range for the standard amyloid protein was between 600 to 1800 $\mathrm{cm}^{-1}$, which corresponds to the different molecules including tyrosine $\left(800 \mathrm{~cm}^{-1}\right)$, phenylalanine $\left(1000 \mathrm{~cm}^{1}\right)$, tyrosine-phenyl $\left(1100 \mathrm{~cm}^{-1}\right)$, amide I $\left(1500 \mathrm{~cm}^{-1}\right)$, amide II $\left(1600 \mathrm{~cm}^{-1}\right)$, amide III $(1200-1300 \mathrm{~cm}$ $\left.{ }^{1}\right)$. For instance, for plasma plus extract of DNA amyloid sensor, the range of the fingerprint was similar to the range of the plasma alone. However, the number of peaks of the plasma plus extract was higher (10 peaks) for group 1, followed by group 2 (8 peaks) and group 3 (6 peaks). The intensity varied according to the group in which group 2 showed the highest intensity (Figure 5); while for plasma alone, group 1 showed 7-8 peaks similar to the standard amyloid with the highest intensity $\left(>2000 \mathrm{~cm}^{-1}\right)$. Group 2 showed 8 peaks with lower intensity (approximately $1,000 \mathrm{~cm}^{-1}$ ), and group 3 showed 5-6 peaks and the lowest intensity $\left(600 \mathrm{~cm}^{-1}\right.$ ) (data not showing due to large size of the figure), but it only showed one peak specific for amyloid protein, with the other 3 peaks related to an amide compound (i.e. $1200-1600 \mathrm{~cm}^{-1}$ ) common to any protein analyzed by Raman spectroscopy.

Figure 5 Raman spectroscopy analysis of samples. This figure illustrates the results of the Raman spectroscopy analysis for samples from different patient groups based on the plasma plus DNA amyloid sensor as compared to the standard amyloid protein

\section{Determination particle size of the DNA amyloid sensor}

Both the DNA Amyloid sensor and the control of synthesized amyloid protein, showed close particle size, $124 \mathrm{~nm}$ and $95 \mathrm{~nm}$, respectively (Figure 6), in relation to the full length of Amyloid protein (i.e. $110 \mathrm{KDa}$ ).

\section{Determination of the molecular weight of the DNA amyloid sensor}

The extract from the DNA amyloid yeast culture produced amyloid protein after filtration in centrifugal devices within the range of 30 to $100 \mathrm{kDa}$ as well as in gel electrophoresis (Figure 7). However, sample extracts from DNA amyloid yeast exhibit the highest and strongest molecular weight as shown by the thickness and brightness of the bands in the gel electrophoresis (Figure 7), as compared to the control reference fragments which showed lighter brightness and weaker bands (Figure 7).

Comparative results between fluorescence of the DNA $\beta$-Amyloid sensor mixed with patient blood plasma, and MRI, and medical diagnosis.

The comparative results between fluorescence produced by the $\beta$-amyloid sensor with MRI and medical diagnosis from patients in all three groups showed good correlation (Table 1) (Figure 8), which confirms the efficacy of the $\beta$-amyloid sensor for detecting $\beta$-amyloid protein. These results also confirm the reliability of our classification of the three groups (i.e. Alzheimer's Diagnosed, Pre-Alzheimer's, and Normal) based on the intensity of the fluorescence. The correlation was very strong between the fluorescence and the two medical diagnosis criteria (1. memory loss and 2. cognitive impairment such as mental disorientation, and/or mental confusion) according to the group's classification. This strong correlation was followed by the comparative results of the conventional MRI analysis. The two conventional diagnostic methods described herein (i.e. MRI, and medical diagnosis) all correlated well with our fluorescence results based on the constructed $\beta$-amyloid sensor when used with healthy and/or non-Alzheimer's patients. 
Table 1. Comparative results between fluorescence of the DNA bacterial cell $\square$-Amyloid sensor mixed with patient blood plasma, MRI, and medical diagnosis analysis. This table confirms the efficacy of using fluorescence of blood plasma for diagnosing Alzheimer's symptoms when compared to invasive conventional diagnostic methods such as MRI

\begin{tabular}{|c|c|c|c|c|c|c|}
\hline Patient & Gender & Age & $\begin{array}{l}\text { Conjugation Fluorescence } \\
\text { (FSU) }\end{array}$ & Medical Diagnosis & MRI & Glycemia (mg/dL) \\
\hline \multicolumn{7}{|c|}{ Group 1: Alzheimer's diagnosed } \\
\hline 12 & Female & 77 & 151200 & $\begin{array}{l}\text { Cognitive impairment (Disorientation, } \\
\text { Mental Confusion) and Memory Loss }\end{array}$ & $\begin{array}{c}\text { Sulci widening. Dilatation of the } \\
\text { ventricular system, hippocampal } \\
\text { atrophy }\end{array}$ & 84 \\
\hline 68 & Female & 63 & 143000 & $\begin{array}{l}\text { Cognitive impairment (Disorientation, } \\
\text { Mental Confusion) and Memory Loss }\end{array}$ & $\begin{array}{c}\text { Sulci widening. Dilatation of the } \\
\text { ventricular system, hippocampal } \\
\text { atrophy }\end{array}$ & 102 \\
\hline 59 & Female & 85 & 140000 & $\begin{array}{l}\text { Cognitive impairment (Disorientation, } \\
\text { Mental Confusion) and Memory Loss }\end{array}$ & $\begin{array}{l}\text { Sulci widening. Dilatation of the } \\
\text { ventricular system, hippocampal } \\
\text { atrophy }\end{array}$ & 101 \\
\hline 67 & Female & 75 & 152300 & $\begin{array}{l}\text { Cognitive impairment (Disorientation, } \\
\text { Mental Confusion) and Memory Loss }\end{array}$ & $\begin{array}{c}\text { Sulci widening. Dilatation of the } \\
\text { ventricular system, hippocampal } \\
\text { atrophy }\end{array}$ & 96 \\
\hline 3 & Male & 76 & 161000 & $\begin{array}{l}\text { Cognitive impairment (Disorientation, } \\
\text { and Mental Confusion) }\end{array}$ & $\begin{array}{c}\text { Prominence of ventricular system } \\
\text { and.Sulci widening }\end{array}$ & 87 \\
\hline 9 & Female & 72 & 143800 & $\begin{array}{c}\text { Cognitive impairment (Disorientation, } \\
\text { and Mental Confusion) and Memory } \\
\text { Loss }\end{array}$ & $\begin{array}{c}\text { Prominence of ventricular system } \\
\text { and.sulci widening }\end{array}$ & 91 \\
\hline 69 & Male & 80 & 143200 & $\begin{array}{l}\text { Cognitive impairment (Disorientation, } \\
\text { Mental Confusion) and Memory Loss }\end{array}$ & $\begin{array}{c}\text { Sulci widening. Dilatation of the } \\
\text { ventricular system, hippocampal } \\
\text { atrophy }\end{array}$ & 110 \\
\hline 38 & Male & 75 & 164000 & $\begin{array}{c}\text { Cognitive impairment (Disorientation, } \\
\text { and Mental Confusion) and Memory } \\
\text { Loss }\end{array}$ & $\begin{array}{c}\text { Sulci widening. Dilatation of the } \\
\text { ventricular system, hippocampal } \\
\text { atrophy }\end{array}$ & 75 \\
\hline 8 & Female & 89 & 139300 & $\begin{array}{c}\text { Cognitive impairment (Disorientation, } \\
\text { and Mental Confusion) and Memory } \\
\text { Loss }\end{array}$ & $\begin{array}{c}\text { Sulci widening and hippocampal } \\
\text { atrophy }\end{array}$ & 86 \\
\hline 34 & Male & 80 & 186000 & $\begin{array}{l}\text { Cognitive impairment (Disorientation, } \\
\text { and Mental Confusion) }\end{array}$ & $\begin{array}{c}\text { Sulci widening. Dilatation of the } \\
\text { ventricular system, hippocampal } \\
\text { atrophy }\end{array}$ & 91 \\
\hline 61 & Male & 80 & 146300 & Disorientation and Memory Loss & $\begin{array}{l}\text { Sulci widening. Dilatation of the } \\
\text { ventricular system, hippocampal } \\
\text { atrophy }\end{array}$ & 80 \\
\hline 41 & Male & 84 & 199500 & $\begin{array}{c}\text { Cognitive impairment (Disorientation, } \\
\text { and Mental Confusion) and Memory } \\
\text { Loss }\end{array}$ & $\begin{array}{c}\text { Sulci widening. Dilatation of the } \\
\text { ventricular system, hippocampal } \\
\text { atrophy }\end{array}$ & 93 \\
\hline 40 & Male & 78 & 140000 & $\begin{array}{c}\text { Cognitive impairment (Disorientation, } \\
\text { and Mental Confusion) and Memory } \\
\text { Loss }\end{array}$ & $\begin{array}{c}\text { Sulci widening. Dilatation of the } \\
\text { ventricular system, hippocampal } \\
\text { atrophy }\end{array}$ & 89 \\
\hline 10 & Male & 67 & 156700 & $\begin{array}{l}\text { Cognitive impairment (Disorientation, } \\
\text { Mental Confusion) and Memory Loss }\end{array}$ & $\begin{array}{c}\text { Sulci widening. Dilatation of the } \\
\text { ventricular system, hippocampal } \\
\text { atrophy }\end{array}$ & 87 \\
\hline 48 & Female & 76 & 149500 & Mental confusion and Memory Loss & $\begin{array}{c}\text { Sulci widening. Dilatation of the } \\
\text { ventricular system, hippocampal } \\
\text { atrophy }\end{array}$ & 86 \\
\hline 4 & Female & 78 & 163400 & $\begin{array}{c}\text { Cognitive impairment (Disorientation, } \\
\text { and Mental Confusion) and Memory } \\
\text { loss }\end{array}$ & $\begin{array}{c}\text { Sulci widening. Dilatation of the } \\
\text { ventricular system, hippocampal } \\
\text { atrophy }\end{array}$ & 88 \\
\hline 63 & Female & 75 & 140000 & $\begin{array}{l}\text { Cognitive impairment (Disorientation, } \\
\text { and Mental Confusion) and Memory } \\
\text { loss }\end{array}$ & $\begin{array}{c}\text { Sulci widening. Dilatation of the } \\
\text { ventricular system, hippocampal } \\
\text { atrophy }\end{array}$ & 98 \\
\hline 2 & Female & 77 & 141200 & $\begin{array}{l}\text { Cognitive impairment (Disorientation, } \\
\text { and Mental Confusion) }\end{array}$ & $\begin{array}{c}\text { Sulci widening, dilatation of the } \\
\text { ventricular system, hippocampal } \\
\text { atrophy }\end{array}$ & 87 \\
\hline 6 & Female & 86 & 183600 & $\begin{array}{c}\text { Cognitive impairment (Disorientation, } \\
\text { and Mental Confusion) and Memory } \\
\text { loss }\end{array}$ & $\begin{array}{c}\text { Sulci widening. Dilatation of the } \\
\text { ventricular system, hippocampal } \\
\text { atrophy }\end{array}$ & 89 \\
\hline
\end{tabular}




\begin{tabular}{|c|c|c|c|c|c|c|}
\hline \multicolumn{3}{|c|}{ Total Mean +/- SD } & $158100+/-18700$ & & & \\
\hline \multicolumn{7}{|c|}{ Group 2: Pre- Alzheimer's } \\
\hline $13(2)$ & Male & 57 & 124300 & Asymptomatic & Hippocampal atrophy & 81 \\
\hline $7(2)$ & Female & 78 & 137500 & Memory Loss & Sulci widening & 82 \\
\hline $5(2)$ & Female & 75 & 117100 & Cognitive impairment & $\begin{array}{l}\text { Sulci widening and hippocampal } \\
\text { atrophy }\end{array}$ & 75 \\
\hline 47 & Male & 66 & 139500 & Memory Loss & $\begin{array}{l}\text { Dilatation of the ventricular sys- } \\
\text { tem and hippocampal atrophy }\end{array}$ & 95 \\
\hline 53 & Female & 69 & 136600 & Disorientation and memory loss & $\begin{array}{l}\text { Dilatation of the ventricular sys- } \\
\text { tem and hippocampal atrophy }\end{array}$ & 83 \\
\hline $32(2)$ & Female & 62 & 139000 & Cognitive impairment & Bilateral frontal atrophy. & 85 \\
\hline 54 & Female & 77 & 125300 & Memory Loss & $\begin{array}{l}\text { Sulci widening and slightly hip- } \\
\text { pocampal atrophy }\end{array}$ & 93 \\
\hline 56 & Male & 67 & 116800 & Disorientation and memory loss & $\begin{array}{l}\text { Sulci widening and hippocampal } \\
\text { atrophy }\end{array}$ & 95 \\
\hline 53 & Female & 75 & 114200 & Memory Loss & $\begin{array}{c}\text { Dilatation of the ventricular } \\
\text { system }\end{array}$ & 87 \\
\hline 55 & Male & 71 & 128000 & Memory Loss & $\begin{array}{l}\text { Sulci widening. Dilatation of the } \\
\text { ventricular system, hippocampal } \\
\text { atrophy }\end{array}$ & 105 \\
\hline 33 & Male & 66 & 123500 & $\begin{array}{l}\text { Cognitive impairment (Disorientation, } \\
\text { and Mental Confusion) }\end{array}$ & $\begin{array}{l}\text { Sulci widening. Dilatation of the } \\
\text { ventricular system and Slightly } \\
\text { hippocampal atrophy }\end{array}$ & 123 \\
\hline 50 & Female & 70 & 117300 & Asymptomatic & $\begin{array}{l}\text { Dilatation of the ventricular } \\
\text { system, hippocampal atrophy }\end{array}$ & 80 \\
\hline \multicolumn{3}{|c|}{ Total mean + - SD } & $127700+/-9036$ & & & \\
\hline \multicolumn{7}{|c|}{ Group 3: Healthy } \\
\hline 37 & Male & 80 & 103800 & Healthy & Not signs for Alzheimer disease & 84 \\
\hline 46 & Male & 71 & 74600 & Healthy & Without alterations & 94 \\
\hline 62 & Female & 74 & 105400 & Healthy & Without alterations & 87 \\
\hline 66 & Male & 68 & 89390 & Healthy & Without alterations & 100 \\
\hline 42 & Female & 74 & 105800 & Memory loss & Without alterations & 88 \\
\hline $1(2)$ & Female & 61 & 31000 & Healthy & Without alterations & 97 \\
\hline 64 & Male & 72 & 59670 & Healthy & Without alterations & 90 \\
\hline 36 & Male & 63 & 104200 & Healthy & Without alterations & 87 \\
\hline 44 & Female & 80 & 109300 & Disorientation & Without alterations & 86 \\
\hline 60 & Female & 59 & 78000 & Healthy & Without alterations & 87 \\
\hline 58 & Female & 66 & 44900 & Healthy & Without alterations & 95 \\
\hline 35 & Female & 65 & 65820 & Healthy & Without alterations & 92 \\
\hline 57 & Female & 62 & 60950 & Healthy & Without alterations & 84 \\
\hline 43 & Female & 75 & 106700 & Healthy & Without alterations & 87 \\
\hline 49 & Female & 71 & 60300 & Healthy & Without alterations & 89 \\
\hline 51 & Male & 79 & 72800 & Healthy & Without alterations & 105 \\
\hline 45 & Female & 74 & 98000 & Healthy & Without alterations & 103 \\
\hline 39 & Female & 75 & 110000 & Healthy & Without alterations & 91 \\
\hline 65 & Male & 77 & 80028 & Healthy & Without alterations & 115 \\
\hline \multicolumn{3}{|c|}{ Total mean $+/-\mathrm{SD}$} & $82200+/-23970$ & & & \\
\hline
\end{tabular}

Note 1: FSU = Fluorescence Units, MRI = Magnetic Resonance Imaging

Note 2: The fluorescence of the extract alone ( $4000 \mathrm{FSU})$ was subtracted from each sample fluorescence

Note 3: MRI criteria used in investigation were: 1) Sulci widening, 2) Dilatation of the ventricular system, and 3) hippocampal atrophy. However, in some cases other related MRI criteria was used "bilateral frontal atrophy". This was applied on a Pre- Alzheimer's patients.

Note 4: Medical Diagnosis criteria used was: A) Cognitive impairment ( Mental concussion and/or disorientation) B) Memory Loss

Note 5: Asymptomatic $=$ no symptoms 


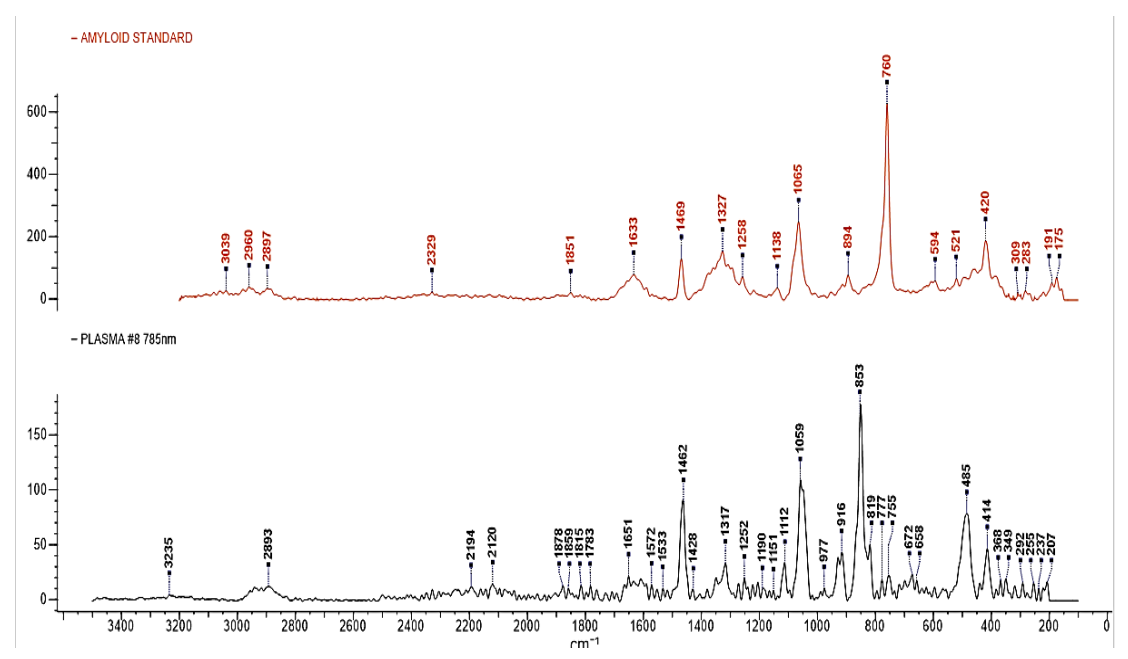

(A)

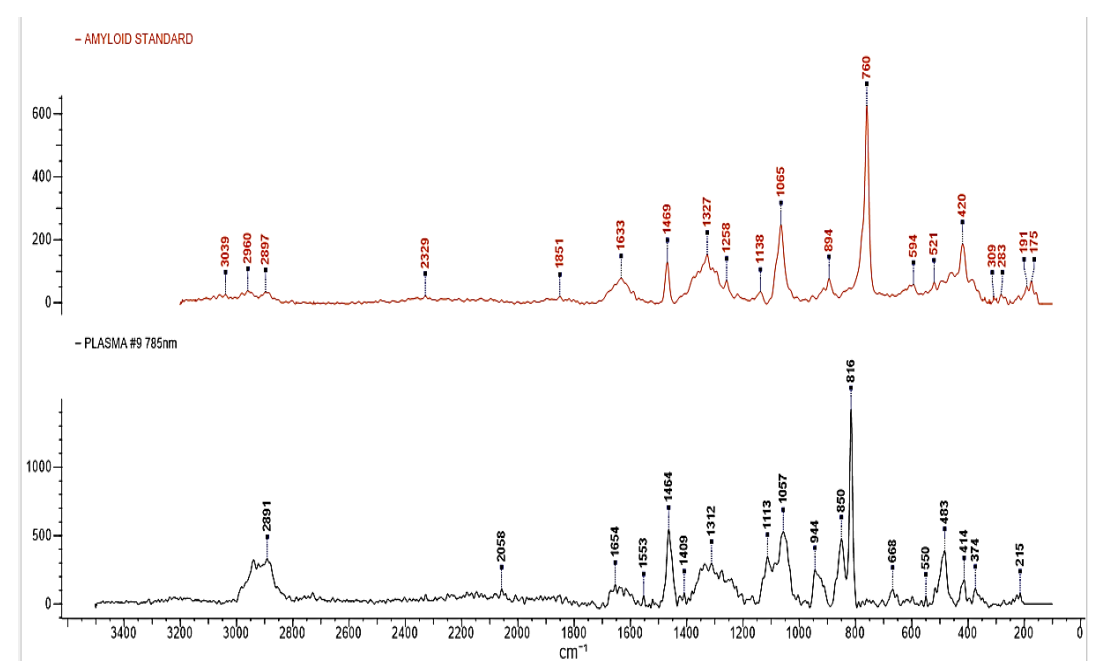

(B)

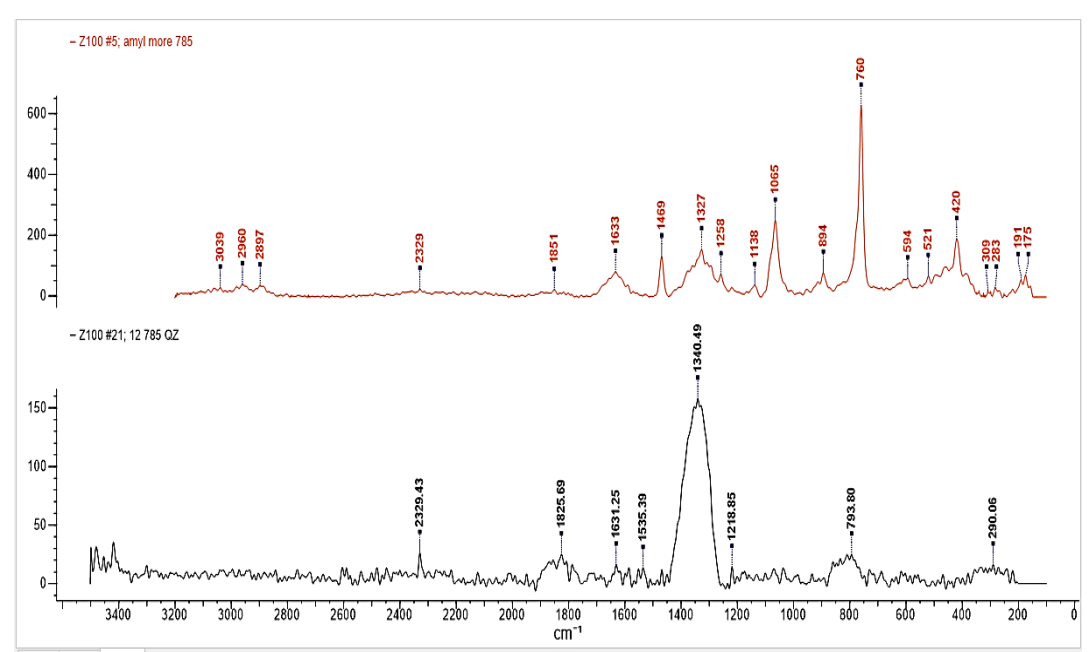

(C)

Figure 5. A. Diagnosed Alzheimer's Plasma +DNA amyloid sensor. B. Pre-Alzheimer Plasma +DNA amyloid sensor. C. Healthy Plasma + DNA amyloid sensor 
Amyloid sensor particle size

\section{Primary Protein Analysis Report v1.0}

Malvern

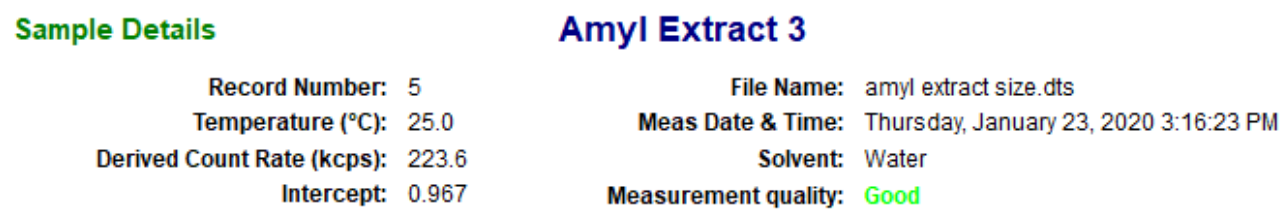

\%Pd

Peak 1: $141.8 \pm 57.00$

Peak $2 \quad 0.000 \pm 0.000$ Est. MW $(\mathrm{KDa})$
$(\text { Mean } \pm \mathrm{SD})^{\star}$

Peak

Peak 3: $0.000 \pm 0.000$

$39.27 .63 e+4 \pm 2.99 \mathrm{e}+4$

$0.0 \pm 0.0$

$\%$ Intensity

100.0

$\%$ Mass Polydispersity

$\begin{array}{ll}0 & 0.0 \pm 0.0 \\ 0 & 0.0 \pm 0.0\end{array}$

0.0

100.0

0.0

Polydisperse
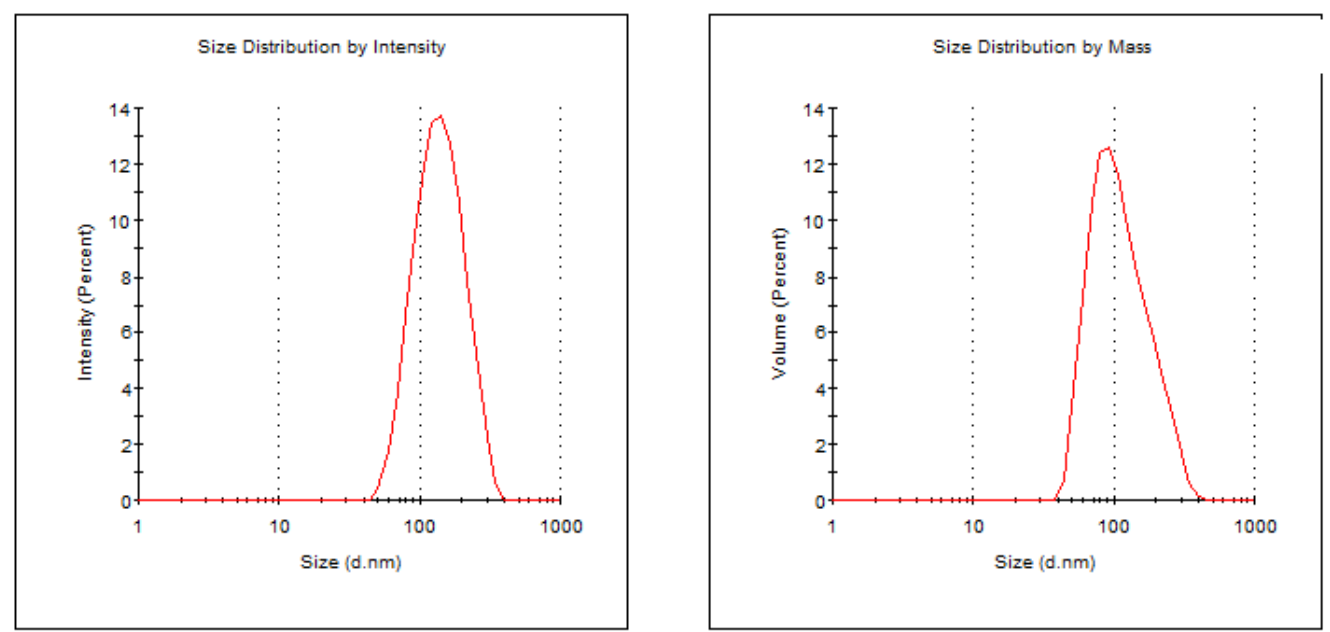

- The molecular weight reported here is only an estimate, calculated using an empirical mass vs. size calibration curve. 
Control, Synthesized Amyloid Protein

\section{Primary Protein Analysis Report}

v1.0

Malvern

\section{Sample Details}

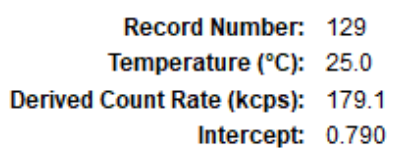

Record Number: 129

Temperature $\left({ }^{\circ} \mathrm{C}\right): 25.0$

Derived Count Rate (kcps): 179.1

Intercept: 0.790

\author{
amylose 2 \\ File Name: size glucose.dts \\ Meas Date \& Time: Monday, January 20, 2020 3:28:08 PM \\ Solvent: tris $500 \mathrm{mmol}$ \\ Measurement quality: Rely on distribution only
}

\section{Hydrodynamic Radius}

Z-Average ( \pm SD) (d.nm): $95.97 \pm 64.88$

Polydispersity Index: 0.457
Estimated MW ( \pm SD) $(\mathrm{KDa}): 2.89 \mathrm{e} 4 \pm 1.95 \mathrm{e}+04$

\%Polydispersity: 67.6

Sample Polydispersity: Polydisperse

\begin{tabular}{|c|c|c|c|c|c|c|}
\hline \multicolumn{3}{|c|}{ Distribution Results } & $\begin{array}{l}\text { Est. MW (KDa) } \\
(\text { Mean } \pm \text { SD)* }\end{array}$ & $\%$ Intensity & $\%$ Mass & \multirow{2}{*}{$\begin{array}{c}\text { Peak } \\
\text { Polydispersity } \\
\text { Polydisperse }\end{array}$} \\
\hline Peak 1: & $105.7 \pm 65.78$ & 53.8 & $5.08 \mathrm{e}+4 \pm 2.74 \mathrm{e}+4$ & 93.8 & 92.2 & \\
\hline Peak 2 & $5560 \pm 721.0$ & 15.0 & $2.75 e+8 \pm 4.11 e+7$ & 6.2 & 7.8 & Monodisperse \\
\hline Peak 3: & $0.000 \pm 0.000$ & 0 & $0.0 \pm 0.0$ & 0.0 & 0.0 & \\
\hline
\end{tabular}
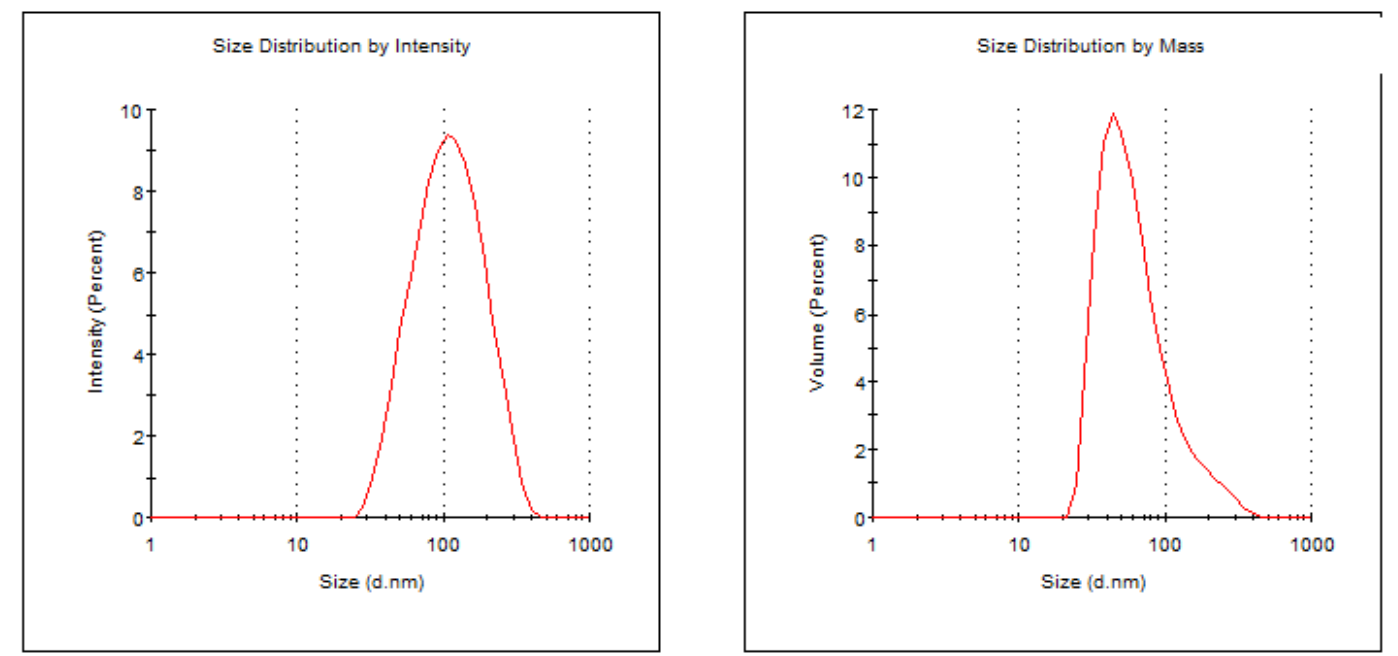

-The molecular weight reported here is only an estimate, calculated using an empirical mass vs. size calibration curve.

Malvem hstruments Ltd www.mavem.com
Zetaizer Ver. 7.11
Serial Number : MAL 500909
File name: Amylaid Standard PSD

File name: Amylad

(B)

Figure 6. A. Illustration of the size distribution by photon-intensity of the particle of the DNA Amyloid Sensor. The peak of the intensity is showing at 124 nm. B. Illustration of the size distribution by photon-intensity of the particle of the Control, Synthesized Amyloid Protein. The peak of the intensity is showing at $95 \mathrm{~nm}$ 


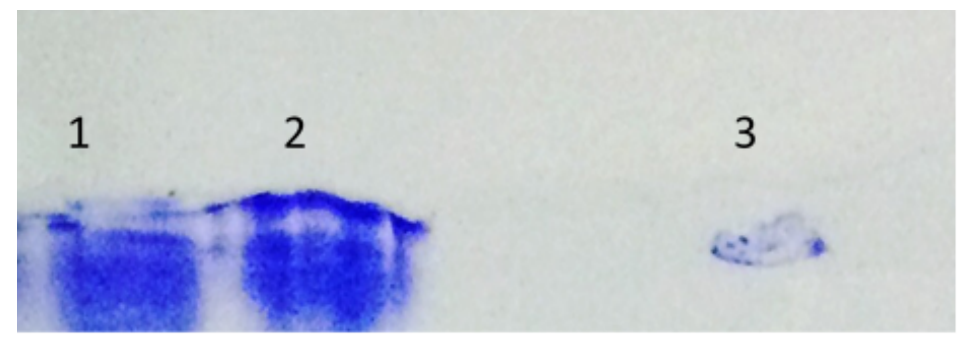

Figure 7. SDS-PAGE protein purification of Alzheimer's Device Extract. 1. Alzheimer's Device extract concentrated by filter 30K. 2. Alzheimer's Device extract concentrated by filter 100K 3. Standard Beta-Amyloid Protein. The purified protein in the extract is larger than $100 \mathrm{KDa}$

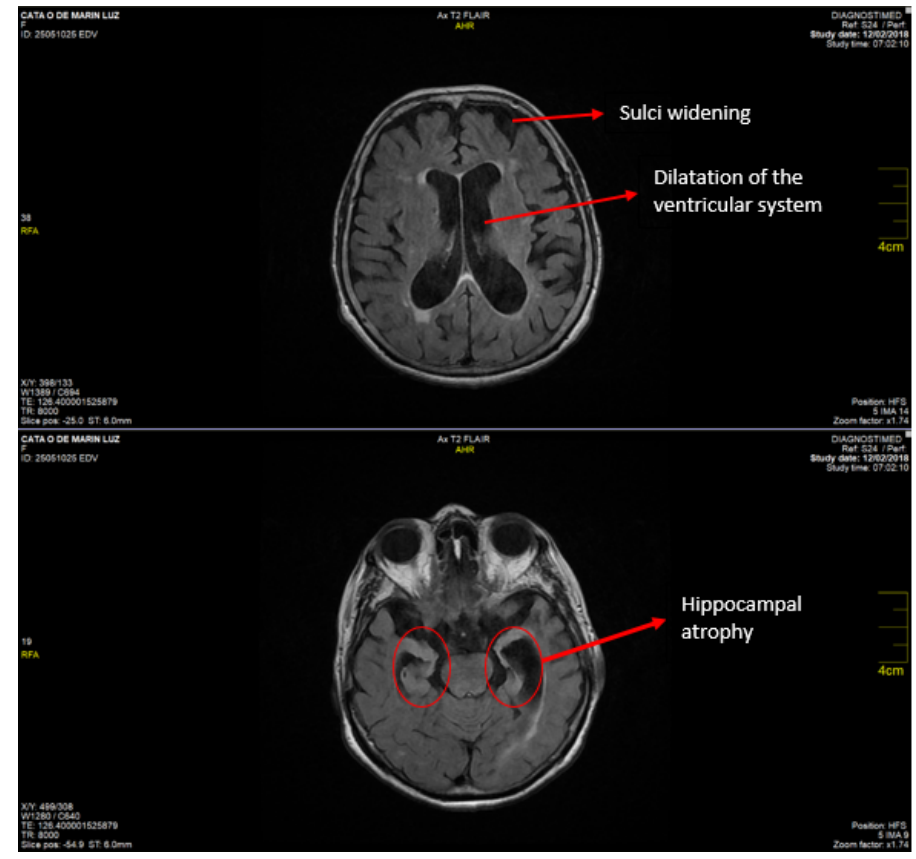

(A)

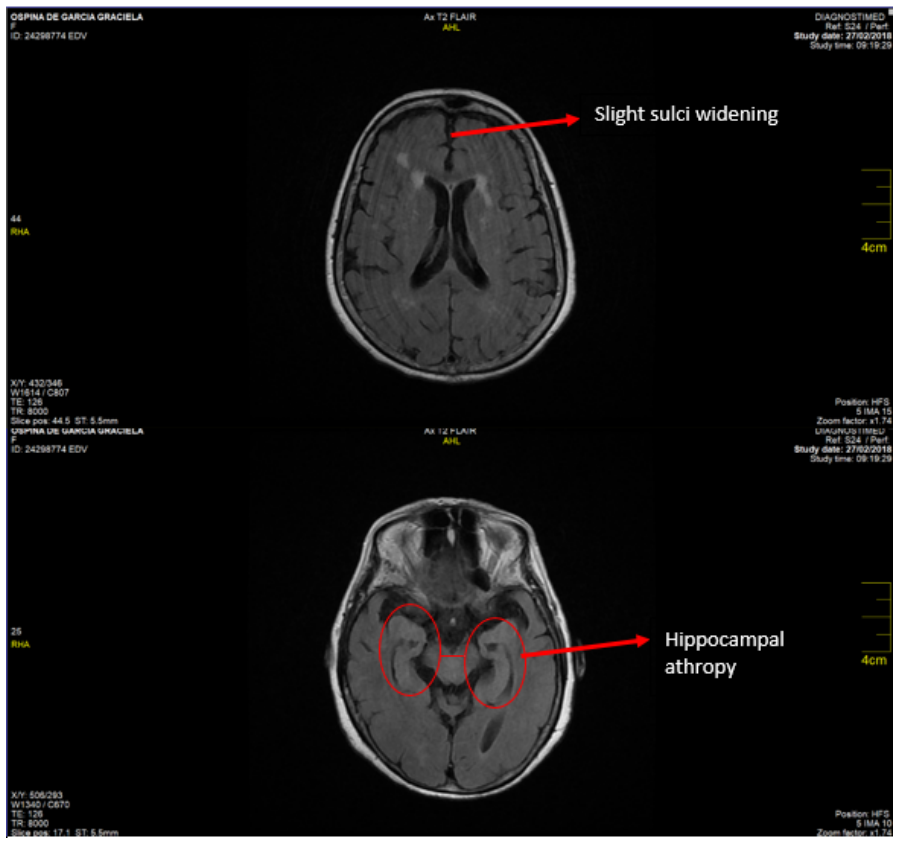

(B) 


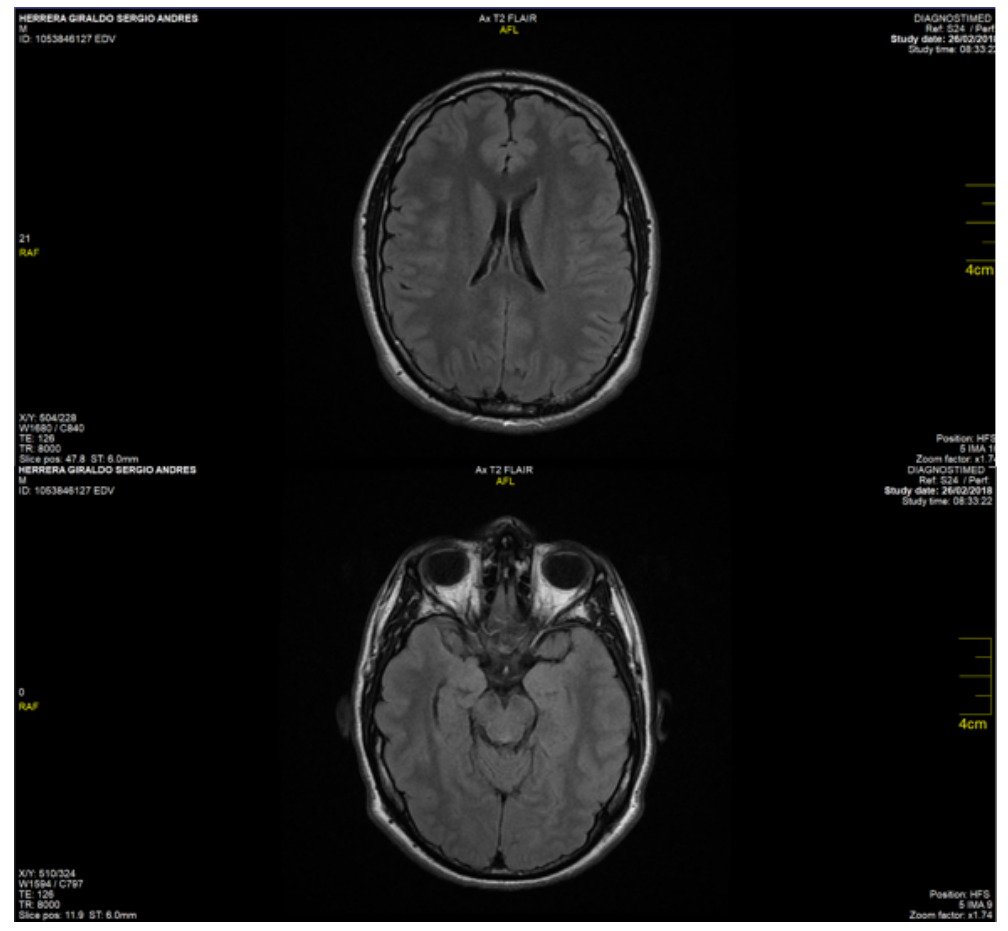

(C)

Figures 8. A. shows the comparative MRI results from patients clinically diagnosed with Alzheimer's versus healthy patients, using extract of yeast DNA $\beta$-Amyloid sensor. B. shows the MRI of pre-Alzheimer's patient (5) using extract of yeast DNA $\beta$-Amyloid sensor. C. shows the MRI of a healthy patient without encephalic alterations [24] using extract of yeast DNA $\beta$-Amyloid sensor

\section{Statistical analysis}

Results showed that the three groups were well categorized based on the three selected parameters. Group 1 showed the highest fluorescence total mean $(158,100+/-18,780$ FSU) followed by Group $2(127,700$ $+/-9036)$, as compared to Group 3, which exhibited the lowest total mean $(82,200+/-23,970)$ (Table 1). The identification of these groups showed a good level of significance $(\alpha=0.05)$ and correlation variance $\left(\mathrm{P}=1.519^{\star} \mathrm{E}-7\right)$ (Table 1). Also, the effect of sex per group and within each group showed a strong positive correlation Pearson coefficient $(\mathrm{R})$ and a significant $\mathrm{p}$-value, but a positive weak correlation for age.

\section{Discussion}

Our approach is an example of molecular sensing, where the molecular product of the $\beta$-amyloid sensors is acting as an amyloidrecombinant protein/antigen that binds to the APP antibody circulating in the blood [15].

There is a direct correlation between the fluorescence produced by the $\beta$-amyloid sensor and the concentration of $\beta$-amyloid protein when tested in vitro and in vivo. The fluorescence of the extract produced by the yeast cells transformed with the DNA construct mixed with blood plasma confirms the suitability of the extract/recombinant protein for detecting amyloid proteins in human blood plasma due to the fact that both yeast and human cells are eukaryotic cells. The high variability of the fluorescence within the Alzheimer's diagnosed Group 1 as compared to less variability within the ranges of the pre-Alzheimer's Group 2 and control/healthy Group 3 is perhaps due to associated factors such as heritage and/or environmental (e.g., metal ions) that are influencing the onset of Alzheimer's disease. However, Group 1 showed higher fluorescence for female than male, as compared to Groups 2 and 3 where there was no difference. This could be due to other unknown associated factors expressed during the onset of the disease related to women's physiology. Age showed weak positive correlation in Groups $1(\mathrm{r}=0.096)$ and $2(\mathrm{r}=0.155)$ and a weak negative correlation in Group $3(r=-0.0687)$. Perhaps, this is because all three groups are within the same close range of age; age is still important with the development of the disease, and the negative value of Group 3 (Healthy) corroborates the good categorization of the groups.

The fluorescence mechanism is based on excitation and emission of photons [12] at the molecular level as illustrated in Figure 4. This was further confirmed at the cellular level when $\beta$-amyloid sensor device cells were grown in media containing different metals $\left(\mathrm{Fe}^{2+}, \mathrm{Cu}^{2+}, \mathrm{Al}^{2+}\right.$, and $\mathrm{Zn}^{2+}$ ) as compared to controls of non-transformed cells. A previous report also using fluorescence to detect glucose for early diagnosis of diabetes suggests a similar hypothetical mechanism [10].

The Raman spectroscopy analysis, which is based on photonicity, confirmed not only the presence of the amyloid protein in the plasma sample but also the efficacy of the DNA amyloid sensor to diagnose Alzheimer's according to its level (Alzheimer's diagnosed, PreAlzheimer's and Healthy) before the onset of the disease. Raman spectroscopy analysis to analyze amyloid protein according the range of fingerprint of the protein has been reported by other authors $(30,31)$. Also, the DNA Amyloid sensor exhibited a particle size similar to the control synthesized amyloid protein, which confirms the atomic similarity between the two molecules. This is also corroborated by the similarity of molecular weight between the two molecules when analyzed by SDS-PAGE Electrophoresis. The slight difference in numbers of the particle size between the Amyloid sensor (124nm) and 
the control synthetic amyloid protein $(95 \mathrm{~nm})$ is perhaps due to the purity of the chemically synthesized amyloid protein as compared to the natural fully synthesized DNA amyloid yeast device that might have small associated aminoacids or proteins or other compounds, due to some modifications such as glycosylation, phosphorylation, and others occurred during the expression of the amyloid protein in the yeast cell, which might cost interference with the photonicity, or spectrum shift, as it always occurs with biomolecules [16].

Additionally, the influence of metals such as iron on the expression of $\beta$-amyloid was corroborated by the sensitive ELISA test. The expression of $\beta$-amyloid has been previously demonstrated by other authors using the ELISA method for cerebrospinal fluid [17]. These results demonstrate the influence of metals on the expression of $\beta$-amyloid proteins, which suggests a possible effect of metals at the molecular level for triggering Alzheimer's disease [18]. Perhaps this correlation was facilitated by the presence of both a riboswitch and an iron ion channel (TonB) in the $\beta$-amyloid sensor. Another report also corroborates the effective function of iron ion channels and riboswitches in DNA metal sensors [19].

The results herein suggest that the medical criteria outlined above were not sufficient to identify the symptoms for the disease at the time when the patients were examined. Medical diagnosis in this instance is performed using subjective methods based on observation and questioning and not on physical testing and/or molecular (biomarker) identification. However, our $\beta$-amyloid sensors can provide more specific and/or stronger criteria for diagnosing Alzheimer's disease since it is based on a more universal molecule or biomarker such as a protein [20]. Therefore, the diagnosis of Alzheimer's disease can be more objective based on the presence of targeted molecules such as $\beta$-amyloid protein [21].

The sensitivity and accuracy of our $\beta$-amyloid sensor for detecting $\beta$-amyloid in relation to Alzheimer's disease is due to the fluorescence produced by the sensor, which is based on photon emission at the molecular and atomic levels that ultimately provide more specific detection. The photonic detection provides a definite advantage for detection of the disease. However, the photon effect can be subject to some variations due to the fact that photonic detection of amyloid protein is based on the energy of quanta taken up by one mole of molecules, which is known as an Einstein. [16]

However, the intensity of the fluorescence can vary when the molar concentration of the substrate is high, which causes photonic interference. Consequently, a yield of the photonics quantum can be determined in order to obtain the full photonic effect [16].

Specific wavelengths were used to induce fluorescence of the $\beta$-amyloid sensor when mixed with plasma samples to determine concentration of $\beta$-amyloid protein. The photon is the mediator for any type of electromagnetic interaction. The photon has no mass or charge and is responsible for producing all electric and magnetic fields. The photons interact with the electron cloud formed by the bonds of the molecules and produce a vibratory effect that is used for the detection, identification and characterization of biological molecules [22].

Hence, the photonics effect is shown by emission of fluorescence, where intensity represents the presence of the biomolecules such as amyloid protein. Using our $\beta$-amyloid sensor, we were able to identify three distinct groups of patients with clear symptoms and/or without symptoms.

The high sensitivity of the $\beta$-amyloid sensor was also corroborated by Western blot test, which showed higher correlation between concentrations of $\beta$-amyloid protein and fluorescence in blood plasma samples.

Finally, the inconsistent correlation between the level of glycemia and fluorescence units (FSU) during the detection of $\beta$-amyloid protein using the $\beta$-amyloid sensor in blood plasma could be explained by the lack of affinity of the units of the measurement parameters between the two analyses. Thus, glycemia levels are measured based on mass of glucose, while fluorescence is based on energy (photon units).

The quantification of fluorescence produced using the sensor and extracts produced herein is a reliable and more practical diagnostic method as demonstrated and confirmed by other sensitive conventional technologies such as MRI and medical diagnostic parameters. Although MRI is a useful anatomical expression of Alzheimer's, it is not always able to fully predict the disease. Also, tomography does not always capture small damages at the cellular level. For instance, the intensity inhomogeneity, and the segmentation of the magnetic resonance imaging are not always accurate [23]. Additionally, the advance state of the disease might affect the condition of the cells, as we have noticed in the denote investigation. Therefore, the sensitivity for early detection of the disease can be diminished.

The reliability of our $\beta$-amyloid sensor is perhaps due to the inherent bioluminescence of the DNA $\beta$-amyloid sensor that is compatible with the blood plasma at the molecular level regardless of the type of amyloid isoform. Although other authors have demonstrated presence of amyloid protein in blood plasma, their results could depend on the type of amyloid isoform [17].

The $\beta$-amyloid sensor described herein detects the amyloid protein regardless of the types of isoforms that are transported through the blood-brain barrier (BBB). The inherent bioluminescence/fluorescence properties of the sensor provides a wider range of sensitivity. This can be explained based on the active transport in the BBB. During transmembrane transport, different amyloid isoforms form that have similar chemical structures [24]. Our $\beta$-amyloid sensor will be able to detect different isoforms. One of the main advantages in constructing the $\beta$-amyloid sensors by synthetic biology for early detection of Alzheimer's disease in blood is the assemblage of exons that are specific sequences for targeting specific proteins. Thus, the production and the expression of the amyloid protein can be more specific [25]. Currently, we are improving the detection method and the sensitivity of the sensors at the molecular and atomic level.

\section{Conclusion}

This work represents an advance in biomedical science because it shows a correlation between the specific fluorescence intensity produced by the DNA $\beta$-amyloid sensor and the concentration of $\beta$-amyloid protein in plasma to predict the onset of Alzheimer's disease, and allowing the classification of patients in three groups, Alzheimer's patients, Pre-Alzheimer's and healthy. Also, the DNA amyloid sensor exhibits nanoparticle characteristics as it was confirmed through the photonicity analysis. The results of the denoted investigation help to better understand the relationship between Alzheimer's and Diabetes. These results warn further studies in order to establish clear causality relationship between Alzheimer's and Diabetes.

\section{Acknowledgments}

This work was supported by the International Park of Creativity Center, Manizales, Colombia. We thank the late Dr. Pablo Medina, M.D., for providing us with patients' blood samples and the respective 
glycemia analysis, as well as for allowing us to carry out the fluorescence analysis of the blood samples at the Clinical Medical MicrobiologyAlvarez-Medina Laboratory, Cali-Colombia. We are also grateful to Dr. Vladimir Cardenas, MD., Radiologist, for his medical advice and interpretation of the tomographies and imaging technology. We thank Clonetex Systems Inc, Austin, TX, USA for providing the synthesized sequences and for technical assistance during the implementation of this work. We also thank the Imagenes Medicas Diagnostic, and DiagnostiMED Center, Manizales-Colombia, for providing the patients, and for clinical medical analysis. We are grateful to Chemist Dalia Zelko, from BioCapital Holdings, Houston, USA, for carrying out the Raman analysis of the samples. Also, we thank Dr. Cecilia Arturo, M.D., for her contribution with medical advice and providing patients. We also thank Dr. Lawrence Villanueva for reviewing the manuscript.

\section{Author contributions} paper.

All authors contributed extensively to the work presented in this

\section{References}

1. Tesker A, Farbman A (1982) A low-molecular weight soluble Pro-tein from bovine lingual epithelium. Journal of Investigative Dermatology 79: 286-292.

2. Dalwadi G, Benson H, Chen Y (2005) Comparison of diafiltration and tangential flow for purification of nanoparticle suspensions. Pharmaceutical Research 22: 2152-62. [Crossref]

3. D'Souza SF (2001) Microbial biosensor. Review Biosensors and Bioelectric 4: 337 353.

4. Sudworth CD, Krasner N (2004) Raman spectroscopy of Alzheimer's diseased tissue. Proc SPIE 5321: 93-101.

5. Liu C (2019) Modulation of B-amyloid aggregation by graphene quantum dots. $R$ Soc Open sci 6: 190271.

6. Erickson H (2009) Size and shape of protein molecules at the nanometer level determined by sedimentation, gel filtration, and electron microscopy. Biological Procedures Online 11: 32-51.

7. Barnham KJ, Bush AI (2008) Metals in Alzheimer's and Parkinson's diseases. Current Opinion in Chemical Biology 12: 222-228.

8. Davis LG, Kuehl WM, Battey JF (1995) Basic methods in molecular biology, second Ed. McGraw-Hill Professional.

9. Cuero R, McKay (2013) Induction and construct UV protective yeast plasmid. Journal of Biotechnology 166: 76-83.
10. Cuero R, Navia J, Agudelo D, Medina P (2017) Construct of DNA glucose sensor yeast plasmid for early detection of diabetes. Journal of Intergrative Obesity and Diabetes 3: $1-9$.

11. Sambrook J, Fritsch EF, Maniatis T (1989) Molecular cloning laboratory manual Second Ed. Cold Spring Harbor Laboratory Press, New York.

12. Reitz JR, Milford FJ, Christy RW (1996) Fundamentals of electromagnetic theory Editor Addison-Wesley Iberoamericana.

13. Trinder P (1969) Determination of glucose in blood using glucose oxidase with an alternative oxygen acceptor. Ann Clin Biochem 6: 24-27.

14. Michael D (2004) Default mode network activity distinguishes Alzheimer's disease from healthy aging: Evidence from functional MRI disease from healthy aging. Proceedings of the National Academy of Sciences of the United States of America. Review. 101: 4637-4642. [Crossref]

15. Allen S, Chen X (1997) Detection of antigen anti-body binding events with the atomic force microscope. Biochemistry 36: 7457-7463.

16. Freifelder D (1985) Principles of physical chemistry with applications to the biological sciences photochemistry, radiation chemistry, and radiobiology. Chapter 18. Jones and Barlett Publishers, Inc, Portola Valley, CA. 749 page.

17. Fukumoto H, Tennis M, Locascio JJ, Hyman BT, Grwodon JH (2003) Age but not diagnosis is the main predictor of plasma amyloid beta-protein level. Arch Neurol 60: 958-64.

18. Barnham KJ, Bush AI (2008) Metals in Alzheimer's and Parkinson's diseases. Current Opinion in Chemical Biology 12: 222-228.

19. Cuero R, Lilly J, McKay DS (2012) Constructed molecular sensor to enhance metal detection by bacterial ribosomal switch-ion channel protein interaction. J of Biotechnol 158: $1-7$

20. Erdmann VA, Barciszewski J (eds.). (2013). DNA and RNA nanobiotechnolo-gies in medicine: Diagnosis and treatment of diseases. Springer science \& business media.

21. Nakamura A, Kaneko N, Villemagne V, Kato T, Doecke J, (2018) High performance plasma amyloid- $\beta$ biomarkers for Alzheimer's disease. Nature 554: 249-254.

22. Bonnier F, Byrne HJ (2012) Understanding the molecular information contained in principal component analysis of vibrational spectra of biological systems. Analyst 137 $322-332$

23. Shafaf I (2011) Image mosaicing for evaluation of MRI brain tissue abnormalitie segmentation study. International Journal of Biology and Biomedical Engineering 5: 181-189.

24. Zlokovic BV (2000) Clearance of amyloid beta- peptide from brain: Transport or Metabolism? Nat Med 6: 718-719.

25. Koonin VE (2006) The origin of introns and their role in eukaryogenesis: a compromise solution to the introns-early versus introns-late debate. Biol Direct 14: 1-22. [Crossref]

Copyright: (C2020 Cuero R. This is an open-access article distributed under the terms of the Creative Commons Attribution License, which permits unrestricted use, distribution, and reproduction in any medium, provided the original author and source are credited. 